\title{
The Effect of Oxalic Acid, the Pathogenicity Factor of Sclerotinia sclerotiorum on the Two Susceptible and Moderately Resistant Lines of Sunflower
}

\author{
Maryam Monazzah ${ }^{1}$, Zohreh Rabiei ${ }^{2}$, Sattar Tahmasebi Enferadi ${ }^{3 *}$ \\ ${ }^{1}$ Department of Plant Pathology, Faculty of Agriculture, Bu-Ali Sina University, Mahdyeh Street, 65175/4161, Hamedan, Iran \\ ${ }^{2}$ Department of Animal Biotechnology, Faculty of Agricultural Biotechnology, National Institute of Genetic Engineering and Biotechnology, Tehran Tehran, Iran \\ ${ }^{3}$ Department of Molecular Plant Biotechnology, Faculty of Agricultural Biotechnology, National Institute of Genetic Engineering and Biotechnology, Tehran, Iran \\ ${ }^{*}$ Corresponding author: Sattar Tahmasebi Enferadi, Department of Animal Biotechnology, Faculty of Agricultural Biotechnology, National Institute of \\ Genetic Engineering and Biotechnology, Tehran Freeway 15 Km, Pajouhesh BLV., 14925/16, Tehran, Iran.Tel.: +98 2144787429 ; Fax: +98 21 44787399, \\ E-mail: tahmasebi@nigeb.ac.ir
}

Received: 14 Feb. 2017; $\quad$ Revised: 5 Nov. 2017; $\quad$ Accepted: 9 Dec. 2017; Published online: 18 Apr. 2018

\begin{abstract}
Background: One of the main sunflower diseases is the white mold Sclerotinia sclerotiorum. The oxalic acid (OA), which is one of the main pathogenicity factors of this fungus, beside the direct toxicity on the host, has other functions such as the disruption of the cell wall and chelating out the calcium ions.

Objectives: Regarding the importance of this disease, it is important to study the reactions of the plant against OA which is a nonspecific toxin of many other necrotrophic fungi.

Materials and Methods: In this study, two susceptible and moderately resistant sunflower lines were inoculated with OA and samples at the first leaf stage were collected within the intervals of 2, 6,12 and 24 hours post inoculation. The expression of five genes related to tricarboxylic acid cycle, including citrate synthase, fumarase, iso-citrate lyase, malate synthase and malate dehydrogenase was studied under OA treatment.

Results: Two hours after the inoculation, no significant change was observed in the expression of the five studied genes in the moderately resistant line. The iso-citrate lyase gene, which is related to glyoxylate cycle (a variation of the tricarboxylic acid cycle), showed no change in the moderately resistant line; however, it showed an increase in the susceptible line. The increase in fumarase gene expression in moderately resistant line was higher than the susceptible line. The result showed the activation of glyoxylate cycle and destruction of fatty acids in the susceptible line.

Conclusions: Activation of glyoxylate cycle indicated induction of senescent symptoms by OA in susceptible line. Increasing in $\mathrm{H}_{2} \mathrm{O}_{2}$ leads to oxidative burst and cell death. Cell death has an apparent benefit for development and growth of necrotrophic pathogens in the plant cells. The study of resistance mechanisms in response to the pathogen is useful for breeding programs to provide lines with higher resistance to this pathogen.

Keywords: Gene expression; Helianthus annuus; oxalic acid; Sclerotinia sclerotiorum.
\end{abstract}

\section{Background}

The sunflower, Helianthus annuus L. is one of the main sources of edible vegetable oil and has health benefits as well. All parts of sunflower have been used in Iran's ancient medicine and Chinese medicine, such as its seeds and pulp, leaves, flower and roots (1). Also, sunflower seeds are one of the main sources of minerals, vitamins, and antioxidants which are used in human and animal food (2).

Sclerotinia sclerotiorum is one of the most devastating and universal plant pathogen (3). S. sclerotiorum attacks over 400 plant species worldwide including soybean
(Glycine max), sunflower (Helianthus annuus) and canola (Brassica napus), peanut (Arachis hypogaea), tobacco (Nicotiana Tabacum), beans (Phaseolus vulgaris), watermelon (Citrullus lanatus) and alfalfa (Medicago sativa) $(4,5)$. In Iran, this necrotrophic pathogen has been reported in commercial crops canola, strawberry (Fragaria $\times$ ananassa), chickpea (Cicer arietinum) in Dezfol, sunflower in Mazandaran, Kordestan and Azerbaijan, lettuce (Lactuca sativa) in Ahwaz and Andimeshk, tomato (Solanum lycopersicum) and eggplant (Solanum melongena) in Zanjan and mulberry (Morus alba) in Gilan province

Copyright (C) 2017 The Author(s); Published by National Institute of Genetic Engineering and Biotechnology. This is an open access article, distributed under the terms of the Creative Commons Attribution-NonCommercial 4.0 International License (http://creativecommons.org/licenses/ by-nc/4.0/) which permits others to copy and redistribute material just in noncommercial usages, provided the original work is properly cited. 
(6). Therefore, one of the main sunflower diseases is white mold Sclerotinia sclerotiorum. The host's pathology systems (pathosystem) is usually studied by proteomics and transcriptomics techniques as well as conventional analytical methods such as GC-MS and LC-MS and HPLC (7).

Oxalic acid (OA) which is the main pathogenicity factor of fungus, besides a direct toxicity on the host, has other functions such as interfering in $\mathrm{pH}$ signaling, increasing the activity of enzymes destroying plant's cell wall, increasing proteinase activity, destroying the cell wall, chelating calcium ions, increasing shikimate dehydrogenase activity, stimulating endopolygalacturonase activity and preventing the diphenol oxidase activity (8-11). OA also binds with calcium ions in infected plant tissues in order to protect growing hypha from toxic concentrations of calcium in plant cells (12) and is known to suppress plant polygalacturonaseinhibiting proteins (11), polyphenol oxidases activities (13) and antioxidant enzymes (14). OA has also two opposing roles, it can suppress oxidative burst in the early stages of infection and subsequently trigger reactive oxygen species (ROS) and programmed cell death (PCD) in plant tissues (7).

The tricarboxylic acid cycle (TCA) intervenes in energy production. This cycle is known also as Krebs or citric acid cycle. The TCA cycle, besides generating energy, provides the precursors required for amino acids and NADH generation, which are used in many other chemical reactions. Since the defense process in the plant is an energy consuming process, the increase in enzyme expression in Krebs cycle helps the plant to generate energy (16). So, it seems it is necessary to study it in pathogen-host interaction. Given that Sclerotinia is a necrotrophic pathogen with a wide host range (7), it is important to investigate the early responses of sunflower to oxalic acid, the main pathogenicity factor of pathogen.

\section{Objectives}

In the present study, we survey the responses of two moderately resistant (AC 4122) and susceptible (Sat1) sunflower lines to oxalic acid elicitor and the changes in five enzymes (citrate synthase, fumarase, iso-citrate lyase, malate synthase and malate dehydrogenase) expression which intervene in tricarboxylic acid cycle in the first stages of inoculation was studied, as well.

\section{Materials and Methods}

\subsection{Preparing Synthetic Oxalic Acid}

The sclerotia of Sclerotinia sclerotiorum collected directly from the stems of infected plants grown on a sunflower field (Karaj, Iran). They were germinated and grown on potato dextrose agar at $25{ }^{\circ} \mathrm{C}$ (17). Discs of $1 \mathrm{~cm}^{2}$ of Sclerotinia hyphae grown in PDA sterile medium was cut by using a sterile scalpel and then were transferred to Erlenmeyer flasks with 1000 $\mathrm{mL}$ of Czapek-Dox liquid medium at $28^{\circ} \mathrm{C}$. After four weeks, when the fungus formed sclerotia, the fungus mycelia were separated from the liquid medium by a sterile cloth and passed through a filter $0.22 \mu \mathrm{m}$ (8). Then, $30 \mu \mathrm{L}$ of the solution was injected into HPLC column by Hamilton syringe. High performance liquid chromatography analysis was performed on the Agilent Eclipse XBD-C18 column (4.6 by 250 $\mathrm{mm}$ ) with ultraviolet detection at $240 \mathrm{~nm}$ (18). For a quantitative analysis of $\mathrm{OA}$ in the liquid medium, the standard curves of OA were plotted and oxalic acid (OA) concentration was determined (18). A stock of $1 \mathrm{mM}$ of OA (Sigma-Aldrich Chemical Co., Germany) was prepared and then diluted equally to the concentration of $\mathrm{OA}$ in fungal culture filtrate (40 $\mathrm{mM})$. It was sterilized for 20 minutes in the autoclave at $121^{\circ} \mathrm{C}$ and under 1 atmosphere pressure. Its $\mathrm{pH}$ was adjusted using dense $\mathrm{NaOH}$ and $\mathrm{HCl}$ on 3.7 and used for inoculation (9).

3.2. Plant Material, Inoculation, and Sampling of Susceptible and Moderately Resistant Sunflower Lines Moderately resistant (AC 4122) and susceptible (Sat1) lines of sunflower have been germinated in a totally random plan in a $1 / 2$ MS (Murashige and Skoog, (Sigma Chemical Co., St Louis, MO, USA) medium containing vitamins (thiamine, nicotinic acid and pyridoxine, (Sigma Chemical Co., St Louis, MO, USA) with three replicates (9). AC 4122 and Sat 1 lines were developed at the University of Udine, Italy (19). The stem of ten-day old seedling at the first leaf stage were gently scratched by using a sterile micropipette (14) and treated with 20 $\mathrm{mL} 40 \mathrm{Mm}$ of OA, $\mathrm{pH}$ 3.7. The samples were collected at 2, 6, 12 and 24 hours post inoculation (hpi). Controls were inoculated by sterile water.

\subsection{RNA Extraction and cDNA Synthesis}

RNA was extracted using RNeasy Plant Mini Kit (Qiagen, CA, USA) (14). After the extraction of mRNA, its quality and quantity were measured by the spectrophotometer (Nano drop) and agarose gel electrophoresis method. First strand cDNA was synthesized using Thermo kit (00168871) (15). In order to confirm the cDNA synthesis, the PCR reaction was performed using GAPDH gene.

3.4. Real-time PCR 
For Real-time PCR reaction, the synthesized cDNA of control samples and treated samples were processed by Roche master mix kit (03515869001) IR Fast Start DNA Master plus SYGR Green Light Cycler and the experiment was conducted in two technical repetitions using a Corbet apparatus. The master of Real-time PCR reaction included enzyme, buffer and dye SYBR green. $\mathrm{Ct}$ of genes was calculated using Rotor gene software and relative gene expression was evaluated according to $\Delta \Delta \mathrm{Ct}$ formula (20). GAPDH was the housekeeping gene. The primers used for each gene and housekeeping gene are listed in Table $\mathbf{1 .}$

\subsection{Protein Extraction}

Protein extraction was done using Liang et al, (21) method with some modifications. At first, one gram of the stem tissue was powdered using liquid nitrogen in a mortar and pestle and transferred to $2 \mathrm{~mL}$ microtubes. Microtubes were filled with cold 10\% Trichloroacetic acid/acetone (w/v) containing 0/07\% (w/v) DTT (Dithiothreitol, (Sigma Chemical Co., St Louis, MO, USA). The samples were vortex and kept at $-20{ }^{\circ} \mathrm{C}$ overnight. Then, they were centrifuged for 20 minutes at $18,000 \times \mathrm{g}, 4^{\circ} \mathrm{C}$.

The supernatant discarded and cold acetone containing $0 / 07 \%(\mathrm{w} / \mathrm{v})$ DTT was added to the pellet and it was washed four times. The pellet was dried completely and the proteins were solubilized in 400 $\mu \mathrm{L}$ rehydration/sample buffer $(8 \mathrm{M}$ urea, $2 \mathrm{M}$ thiourea, 4\% CHAPS and ampholite 3-10). The pellet was vortex vigorously for 1 hour at room temperature. The microtubes were centrifuged for 30 minutes at 18,000 $\times \mathrm{g}, 15^{\circ} \mathrm{C}$. The supernatant was transferred to a new microtube and kept at $-80{ }^{\circ} \mathrm{C}$ until electrophoresis. The protein concentration was determined by Bradford method (9).

\subsection{Two-dimensional Electrophoresis}

In the first dimension, IPG (Immobilized $\mathrm{pH}$ gradient) gel strips with $18 \mathrm{~cm}$ length and $\mathrm{pH}$ range between 3 and 10 (Bio-Rad) were used. IPG strips were rehydrated with rehydration buffer ( $8 \mathrm{M}$ urea, $2 \mathrm{M}$ thiourea, $50 \mathrm{mM}$ DTT, 4\% CHAPS and $0.2 \%$ ampholyte) for 16 hours. Then, the strips were transferred to isoelectrofocusing Amersham GE Healthcare Ettan IPGphor. The second dimension was $12 \%$ acrylamide gel. The strips were equilibrated in equilibration buffer (6 M urea, 4\% SDS, 30\% glycerol, Tris buffer $0.5 \mathrm{M}, \mathrm{pH} 8.8,5 \%$ iodoacetamide and $1 \%$ DTT). The electrophoresis was done on a constant voltage of 100 volts. The gels were stained by Coomassie Brilliant Blue R250 (23).

\subsection{Gel Electrophoresis Analysis}

Spots were detected by Melanie software 6.02 (GeneBio, Geneva, Switzerland) in the treated and control samples. Then, the protein spots with 1.5 times fold change ( $p \leq 0.05)$ were excised and identified by the Mass spectrometer (MALDI-TOF/TOF) (24). In this study, two spots have been described related to our real time results.

\subsection{Lipid Peroxidation}

Lipid peroxidation was measured by estimation of the malondialdehyde (MDA) content according to the method of Heath and Packer (25) with slight modification.

Table 1. Primer sequences used for real-time PCR analysis.

\begin{tabular}{|c|c|c|}
\hline Gene & Forward (5 to 3 ) & Reverse (5 to 3') \\
\hline Actin & GCTAACAGGGAAAAGATGACTC & ACTGGCATAAAGAGAAAGCACG \\
\hline $\begin{array}{c}\text { Malate } \\
\text { dehydrogenase }\end{array}$ & ATTCACCACCACCAGGCT & TTCTGGAATCTGCCATAG \\
\hline Citrate synthase & CTGATCCAAGATATATGTGC & GCTTTATGAAGTTGTGCCTC \\
\hline Fumarase & AGGGAAGAAAGAGATACC & GTATCGGTGGGCCCCG \\
\hline Isocitrate lyase & GTTGATATGGTACTTGGTG & CGCTTTAGGGGTAGTAGTC \\
\hline
\end{tabular}


MDA content has a direct relationship with the amount of oxidative damage to lipids. One hundred $\mathrm{mg}$ of stem tissues were homogenized in $1 \mathrm{~mL}$ of $0.1 \%$ trichloroacetic acid. The homogenate was centrifuged at $10,000 \times g$ for $5 \mathrm{~min}$. For $500 \mu \mathrm{L}$ of the supernatant, $2 \mathrm{~mL}$ of $20 \%$ trichloroacetic acid containing 0.5\% thiobarbituric acid (Sigma Chemical Co., St Louis, MO, USA) was added. The mixture was placed into a hot water bath at $95{ }^{\circ} \mathrm{C}$ for $30 \mathrm{~min}$ and then cooled quickly on the ice bath. The mixture was centrifuged at $10,000 \times g$ for $20 \mathrm{~min}$. The absorbance of the supernatant was measured at 532 and $600 \mathrm{~nm}$. The non-specific absorbance at $600 \mathrm{~nm}$ was subtracted from the value of $532 \mathrm{~nm}$. MDA concentration was calculated using the extinction coefficient of MDA at $155 \mathrm{mM} \cdot \mathrm{cm}^{-1}$.

\subsection{Statistical Analysis}

The experiment was done in a completely random plan with three replicates for each treatment. All data were analyzed with ANOVA method followed by Duncan test using the SPSS software (version 16). The difference between the groups was considered significant when the probability coefficient was less than $5 \%(p \leq 0.05)$.

\section{Results}

The mRNA expression levels of TCA cycle genes, malate dehydrogenase, citrate synthase, fumarase, malate synthase and isocitrate lyase were analysed by real-time PCR. The results of relative gene expression and the comparison of the mean of relative gene expression in both lines and sampling times has been shown in Table 2 and Figures $\mathbf{1}$ A, B, C, D, and $\mathbf{E}$.

After two hours of oxalic acid (OA) treatment, there were no significant differences in the gene expression of the treated moderately resistant line and the control one, while in the susceptible line, the expression of these genes including malate dehydrogenase, citrate synthase, fumarase, malate synthase and isocitrate lyase increased significantly in the treatments with OA. In 6 hours post inoculation in the moderately resistant line, expression of fumarase (EC 4.2.1.2) gene was more than that in the susceptible line, while iso-citrate lyase (EC 4.1.3.1) gene expression in the susceptible line was more than that in the moderately resistant line. In 12 hours post inoculation, fumarase gene expression in moderately resistant line was more than that in the susceptible line. In 24 hours post inoculation, the

Table 2. The relative gene expression during sampling times and the comparison of the means of relative gene expression by Duncan test.

\begin{tabular}{|c|c|c|c|c|c|c|}
\hline $\begin{array}{l}\text { Sampling time } \\
\text { (hours post } \\
\text { inoculation) }\end{array}$ & Sunflower Line & $\begin{array}{c}\text { Citrate } \\
\text { synthase }\end{array}$ & Fumarase & $\begin{array}{c}\text { Malate } \\
\text { dehydrogenase }\end{array}$ & $\begin{array}{l}\text { Iso-citrate } \\
\text { lyase }\end{array}$ & $\begin{array}{c}\text { Malate } \\
\text { synthesis }\end{array}$ \\
\hline 2 & $\begin{array}{l}\text { Moderately resistant } \\
\text { (AC 4122) }\end{array}$ & $0.88^{-\mathrm{d}}$ & $1.42^{-\mathrm{d}}$ & $1.84^{-\mathrm{c}}$ & $0.91^{-\mathrm{a}}$ & $0.43^{-\mathrm{c}}$ \\
\hline 2 & $\begin{array}{l}\text { Susceptible } \\
\quad \text { (Sat1) }\end{array}$ & $1.85^{\mathrm{cc}}$ & $4.37^{+\mathrm{a}}$ & $4.52^{+c}$ & $3.19^{+b}$ & $3.19^{+\mathrm{c}}$ \\
\hline 6 & $\begin{array}{l}\text { Moderately resistant } \\
\text { (AC 4122) }\end{array}$ & $1.94^{+\mathrm{c}}$ & $2.26^{+d}$ & $2.59^{+\mathrm{c}}$ & $1.53^{-\mathrm{a}}$ & $1.78^{-\mathrm{a}}$ \\
\hline 6 & Susceptible (Sat1) & $1.58^{+\mathrm{c}}$ & $2.01+b c$ & $1.05^{-\mathrm{c}}$ & $7.99^{+b}$ & $27.08^{+b}$ \\
\hline 12 & $\begin{array}{l}\text { Moderately resistant } \\
\text { (AC 4122) }\end{array}$ & $4.25^{\mathrm{+a}}$ & $16.41^{\mathrm{+a}}$ & $3.1^{+b}$ & $0.837^{-\mathrm{a}}$ & $2.83^{+a}$ \\
\hline 12 & Susceptible (Sat1) & $2.74^{+\mathrm{a}}$ & $2.72^{+b}$ & $3.72^{+b}$ & $6.47^{+b}$ & $26.47^{-\mathrm{a}}$ \\
\hline 24 & $\begin{array}{l}\text { Moderately resistant } \\
\text { (AC 4122) }\end{array}$ & $2.25^{+b}$ & $2.43^{+\mathrm{c}}$ & $37.7^{+\mathrm{a}}$ & $2.52^{-\mathrm{a}}$ & $1.51^{-b}$ \\
\hline 24 & Susceptible (Sat1) & $2.78^{+a}$ & $1.69^{+\mathrm{c}}$ & $66.68^{+a}$ & $52.93^{+a}$ & $28.33^{+a}$ \\
\hline
\end{tabular}

no significant difference between control and treatment.

${ }^{+}$significant difference between control and the treatment.

* There are no significant differences between treatments that share the similar letter $(p \leq 0.05)$. 

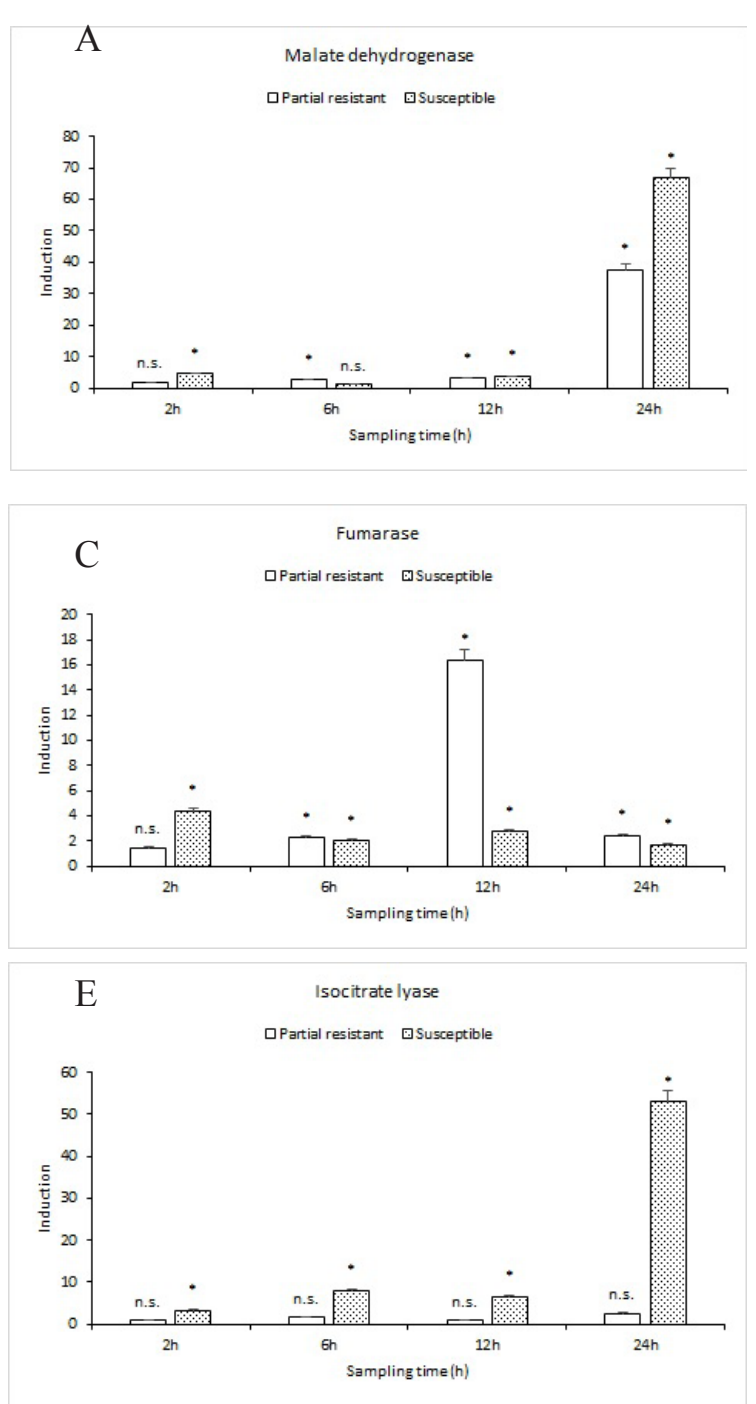

expression of malate dehydrogenase (EC 1.1.1.37) and iso-citrate lyase genes were more pronounced in the susceptible line. The differences in the iso-citrate lyase gene expression between control and inoculated plants disappeared in the moderately resistant in all sampling times, whereas the expression of this gene was more pronounced in the susceptible line.
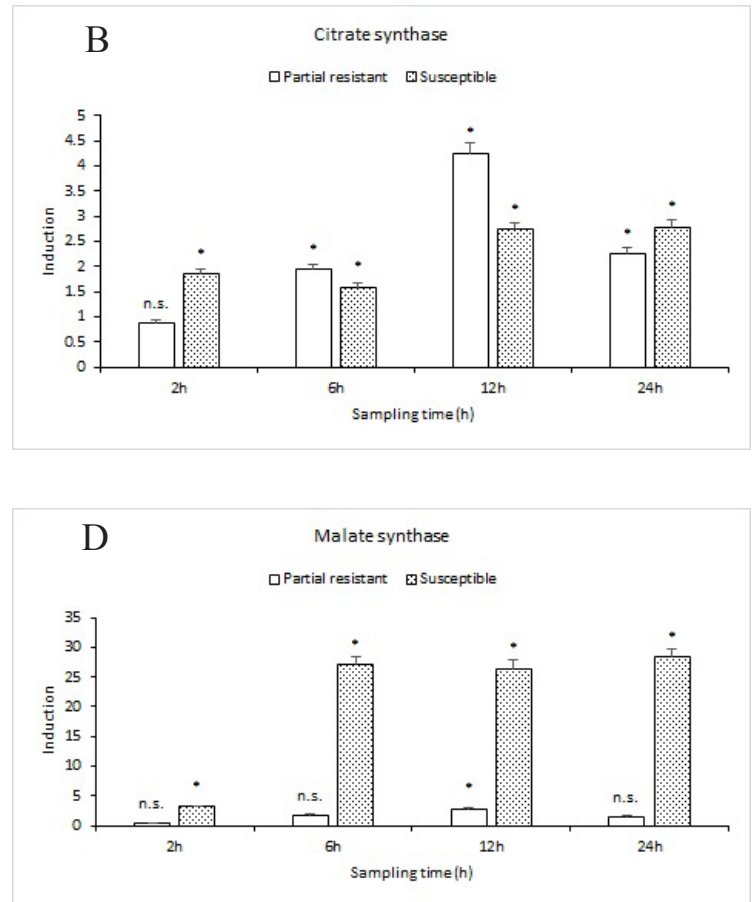

Figure 1. Relative expression of malate dehydrogenase (A), citrate synthase (B), fumarase (C) malate synthase (D) and iso-citrate lyase obtained by real time-PCR in susceptible (Sat1) and moderately resistant lines (AC 4122) during 2,6,12 and 24 hours post.

Table 3. The differentially expressed proteins identified by MS/MS analysis in response to oxalic acid.

\begin{tabular}{|c|c|c|c|c|c|}
\hline \multirow{2}{*}{ Spot number } & \multirow{2}{*}{ NCBI Accession No. } & \multirow{2}{*}{ Protein name } & \multirow{2}{*}{ Mascot score } & \multicolumn{2}{|c|}{ MW (kDa)-pI } \\
\hline & & & & Observed & Theoretical \\
\hline 1 & AAK15147.1 & $\begin{array}{c}\text { Isocitrate lyase [Ipomoea } \\
\text { batatas] (Sweet potato) }\end{array}$ & 145 & $17-5.9$ & $12.1-8.9$ \\
\hline 2 & XP_004152519.1 & $\begin{array}{l}\text { Malate synthase, } \\
\text { glyoxysomal [Cucumis } \\
\text { sativus] }\end{array}$ & 151 & $66-5.1$ & $65-8.4$ \\
\hline
\end{tabular}



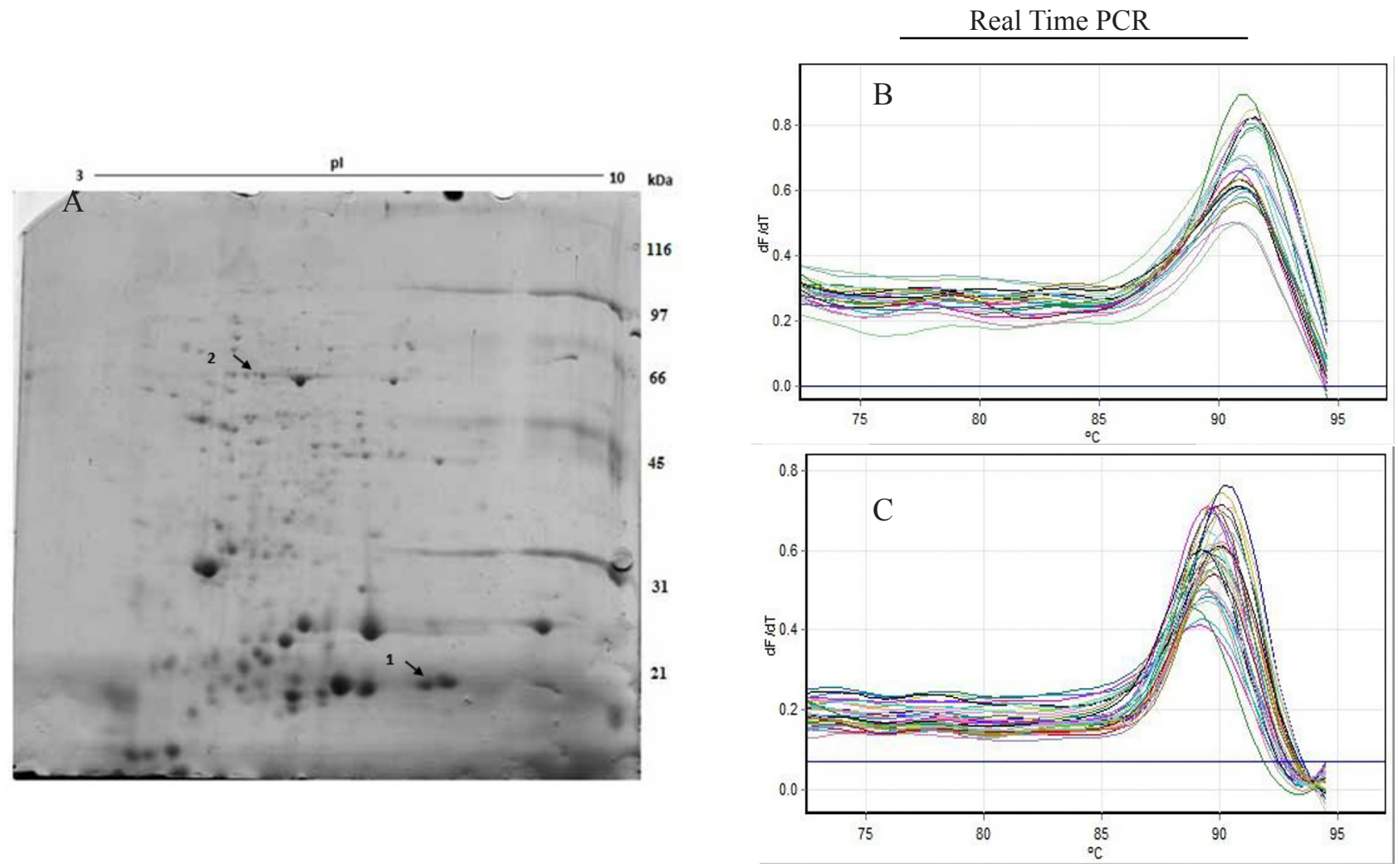

Figure 2. Two-dimensional gel electrophoresis (A) and melting curve of real-time PCR of malate dehydrogenase (B) and iso-citrate lyase $(\mathbf{C})$ genes in susceptible line treated with oxalic acid. Arrows show the identified protein spots.

A

Spot 2

Malate synthase

B

Spot 1

Isocitrate lyase
2DE- Susceptible line

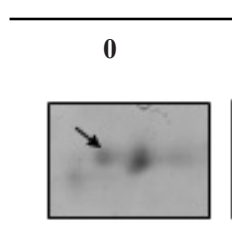

2DE-Susceptible line
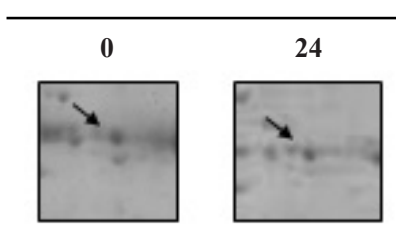

hpi

24 hpi

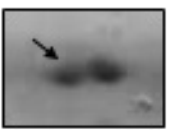

Malate synthase

$\square$ Partail resistant $\square$ Susceptible

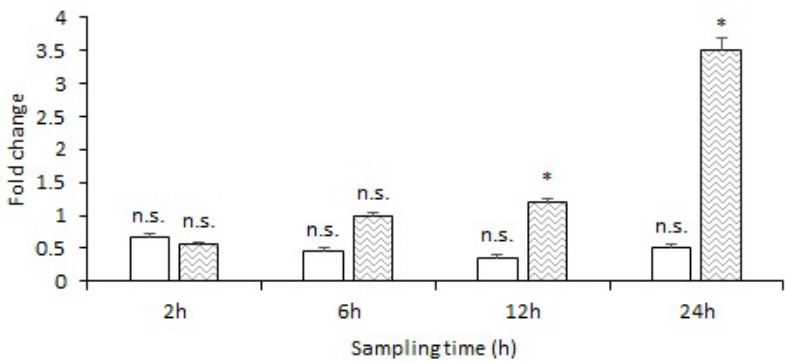

Isocitrate lyase

$\square$ Partail resistant $\square$ Susceptible

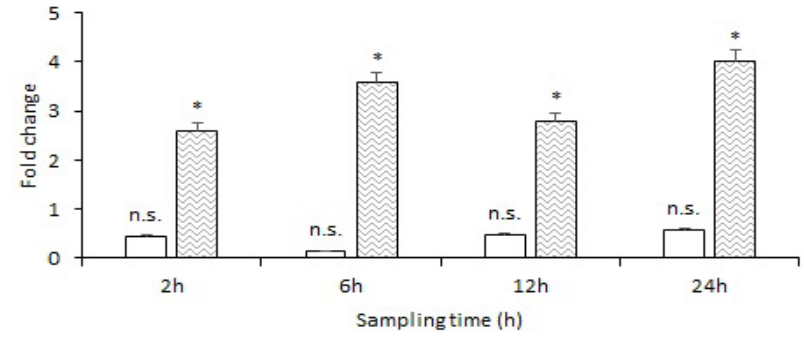

Figure 3. Close view of spot 2 in susceptible (Sat1) line at 0 and 24 hpi (left panel) and its expression during the sampling times in susceptible (Sat1) and moderately resistant lines (AC 4122) (right panel) (A). Close view of spot 1 in susceptible (Sat1) line at 0 and 24 hpi (left panel) and its expression during the sampling times in susceptible (Sat1) and moderately resistant lines (AC 4122) (right panel) (B). 


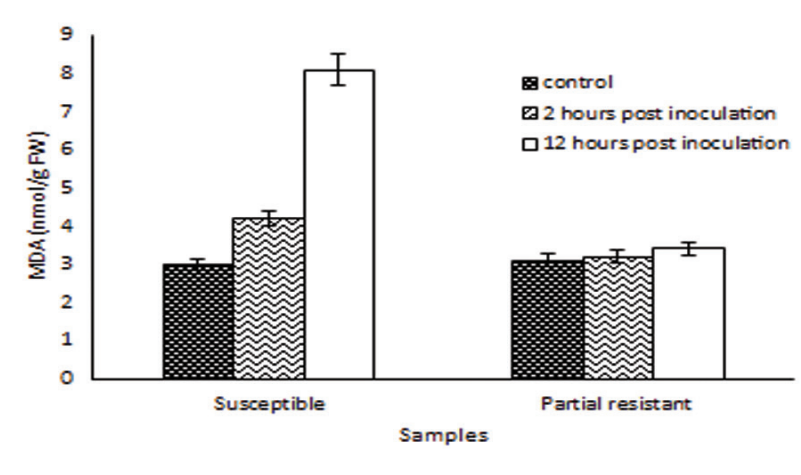

Figure 4. Level of malondialdehyde content in the basal stem of susceptible (Sat1) and moderately resistant (AC 4122) lines inoculated by the oxalic acid.

MDA quantity in moderately resistant, susceptible lines and the controls is shown in Figure 4. In susceptible lines, significant increase in MDA occurred at 2 and 12 $\mathrm{h}$ post inoculation, while in moderately resistant lines, there was no significant increase in MDA content.

\section{Discussion}

The expression of the enzymes related to photosynthesis, Calvin cycle and TCA in microarray analysis and ESTs in incompatible interactions between plant and pathogen have been reported (26). The increase in enzymes expression involved in Calvin cycle and other enzymes in TCA cycle such as glutamine synthase and malate dehydrogenase have been reported in Brassica napusLeptosphaeria maculans interaction in resistant lines at 48 hpi (27). TCA cycle has a key role in production of fats, sterols and amino acids. From $\alpha$-Ketoglutarate in this cycle, proline which is a non-enzymatic antioxidant, is produced. Proline is an amino acid that functions in ROS elimination and prevents the cell death induction induced by oxalic acid (OA) in tissues $(28,29)$.

In the TCA cycle oxaloacetate is decarboxylated to phosphoenolpyruvate which can then be used to generate sucrose (hexose phosphate) in gluconeogenesis pathway. Sucrose contributes in plant metabolism by serving as the source of carbon and energy, it is also known as a signal molecule which can induce plant defense responses such as anthocyanins, a group of flavonoid compounds $(30,31)$. Phosphoenolpyruvate is one of the two starting materials for shikimic acid pathway. Shikimic acid pathway is responsible for producing aromatic amino acids such as Phenylalanine $(32,33)$.

In phenylpropanoid pathway, phenylalanine ammonia lyase convert L-phenylalanine to transcinnamic acid, which is the necessary precursor for synthesis of many compounds such as lignin, lignans, flavonoids and phytoalexins (34-37). Therefore, according to previous studies TCA cycle is at the center of metabolism and production of many compounds involving in defense responses. Transcriptomics and genetics data demonstrated that elicitors of pathogen evoke the expression of genes involved in carbohydrate metabolism pathways such as TCA cycle. The expression of these genes impacts numerous defense responses including PR genes expression and ROS generation (38). Changes in the carbon/nitrogen balance have been identified as a general plant response to pathogen attack. Differential expressions of the enzyme-encoding genes linked with TCA cycle have been observed during plant-pathogen interaction (39). The TCA cycle intermediates including citrate, malate, succinate and fumarate increase significantly during the necrotrophic phase of Magnaporthe grisea infection (40). Isocitrate increased markedly during maize leaves colonization by necrotrophic fungus Colletotrichum graminicola. In C. graminicola infected leaves, expression of TCA cycle enzyme also induced significantly, suggesting that necrotrophic pathogens might commonly induce carboxylate production through the TCA cycle. This can provide plentiful supply of ATP to the plant tissues and increases the activity of TCA cycle accompanied with increasing the respiratory flux as a result of impaired photosynthesis during necrotrophic growth (41). Furthermore, upon the interaction between necrotrophic fungal pathogen Cochliobolus miyabeanus and rice, the protein abundance of enzymes involved in TCA cycle is increased (42).

In this study, two hours post inoculation, the expression of studied genes in the moderately resistant lines had no significant differences from the controls, which could be as a result of resistance of plants against influence of OA at the early stage of inoculation. In sunflowers, one of the well-known mechanisms of plant responses to $S$. sclerotiorum is the accumulation of phenolic compounds in plant cell walls and lignification $(43,44)$. In our previous study, increased activity of phenylalanine ammonia-lyase (PAL) which is one the key enzymes in the biosynthesis of important phenolic derivatives such as lignin, was very pronounced in moderately resistant line AC 4122 inoculated by Sclerotinia culture filtrate (45). Similar to phenolic compounds and PAL, Shikimate dehydrogenase (SKDH) (EC 1.1.1.25) is essential for aromatic amino acid biosynthesis and subsequently lignin production. Tahmasebi Enferadi et al., (9) reported that SKDH 
activity showed considerable increase in moderately resistant and susceptible lines treated with synthetic OA. Therefore, based on the previous studies, in moderately resistant line cell wall might act as a physical barrier against OA penetration into tissues and prevented the activation of TCA cycle. However, the influence was obvious in the susceptible line and two hours post inoculation, the genes expression increased significantly in OA treatments compared to the controls. The expression of all five genes in the susceptible line has been higher than that in the moderately resistant line at $2 \mathrm{hpi}$, which shows OA penetration to the susceptible line cells and its influence on TCA cycle. In the moderately resistant line, at 6 hpi an increase in the expression of the studied genes, except for iso-citrate lyase and malate synthase, has been observed. Since iso-citrate lyase and malate synthase had no changes in the moderately resistant line during none of the sampling times, it could be concluded that glyoxylate cycle has not been activated. Therefore, it seems that only TCA cycle has been activated in the moderately resistant line. The higher expression of fumarase in the moderately resistant line in comparison with the susceptible line also confirms the more activity of TCA cycle in this line. In the susceptible line, glyoxylate cycle played roles in providing the energy, as well. The expression of fumarase in moderately resistant line and malate synthase in susceptible line might lead to increase in malate content in plant tissues. Gene expression profiles of two coffee genotypes, susceptible and resistant to leaf miner (Leucoptera coffella) indicated that the expression of isocitrate lyase and fumarase genes decreased significantly in resistant plants and therefore malate content decreased in those leaves (46). Graham et al. (47) reported that gene expression of malate synthase increased in senescing leaves and petals of cucumber plants.

Upregulation of the glyoxylate cycle genes including iso-citrate lyase and malate synthase confirms the activity of glyoxylate cycle in susceptible lines. The glyoxylate cycle is activated by lipids catabolism for acetyl CoA production along with $\mathrm{H}_{2} \mathrm{O}_{2}$ production and allows the cells to use simple carbon compounds as carbon resource when there are no complex carbon resources such as glucose (48). Activation of glyoxylate cycle indicate induction of senescent symptoms by OA in peroxisomes of susceptible line $(48,49)$. Increase in $\mathrm{H}_{2} \mathrm{O}_{2}$ leads to oxidative burst and cell death. Cell death has an apparent benefit for development and growth of necrotrophic pathogens in the plant cells. However, in the moderately resistant line, TCA cycle continues by an increase in fumarase activity and no destructive effects of fatty acids degradation has been occurred during inoculation. Scheideler et al., (50) reported that isocitrate lyase and oxalyl-CoA decarboxylase transcripts were up-regulated in Arabidopsis thalianaPseudomonas syringae $p v$. tomato interaction. They reported these results as a novel observation in plant defense responses. Oxidation of the fatty acids might be used to generate energy during plant defense responses. It has been shown that glyoxylate cycle enzymes such as malate synthase and isocitrate lyase are synthesized in senescing pumpkin cotyledons (51) and also senescing leaves of rice and wheat (52). $\beta$-oxidation and breakdown of lipid have also been demonstrated in some of these cases. The expression of malate synthase gene was upregulated in those tissues with lipid breakdown and low level of sugar concentration. Graham et al., (47) reported that malate synthase gene expression increased markedly in detached and darkincubated leaves of cucumber. In the dark-incubated leaves, photosynthesis was prevented, chlorophyll and lipid were degraded more rapidly compared to the detached and light-incubated leaves.

In our study, activation of glyoxylate cycle in susceptible line could be as a consequence of lipid peroxidation and prevention of photosynthesis in necrotic tissues. S. sclerotiorum secrete OA in tissues, which leads to the induction of cell death and disruption of membrane integrity, as well (53). Besides the role of lipids in energy production, it has a role in cell membrane integrity. Structural changes of lipid could modify the permeability and integrity of cell membrane. Lipid peroxidation leads to MDA accumulation in plant tissues (54). In the present study lipid peroxidation was estimated by assessing the changes in MDA content. This method is considered as a reliable marker for oxidative stress (55). In the previous study increased levels of MDA was reported in Capsicum annuum fruits - Botrytis cinerea interaction (56). In the present study, MDA content was elevated significantly in susceptible lines compared to un-treated controls, while no significant increases in the levels of MDA were observed in the moderately resistant line comparing controls. MDA accumulation in susceptible line could be as a result of lipid peroxidation and oxidative stress generated by OA treatment. Differential expression of TCA cycle enzymes in susceptible and moderately resistant lines could be due to differential respiratory rate between the two lines.

The expression of malate dehydrogenase and citrate synthase enzymes were similar in both lines except at 2 hpi, which these two genes had no expression in the moderately resistant line. The expression of these 
enzymes increased significantly in both moderately resistant and susceptible lines which might lead to increase in citrate content in both lines. However, Peluffo et al, (57) confirmed that sunflower RHA801 (resistant) contained significantly higher levels of citrate and isocitrate at 4 and 12 days after inoculation with Sclerotinia sclerotiorum when compared with a susceptible sunflower genotype (HA89).

The resistance of sunflower to Sclerotinia sclerotiorum has a polygenic mechanism and the role of many genes and biochemical pathways have not been obviously identified yet in plant resistance system (58). The study of resistance mechanisms and genes which change significantly in response to pathogens can be useful for breeding of sunflower lines in order to provide lines with higher resistance to this devastating necrotrophic pathogen.

\section{Conclusions}

Activation of glyoxylate cycle in susceptible line treated by oxalic acid (OA) indicates degradation of fatty acid and induction of senescent symptoms. Senescent symptoms related to oxidative stress which is a benefit for development and growth of necrotrophic pathogens in the plant cells. However, the successful defense mechanism in taking over the pathogen attack is involved with $\mathrm{H}_{2} \mathrm{O}_{2}$ augmentation which leads to oxidative burst and cell death. It's apparent that cell death is a benefit for development and growth of necrotrophic pathogens in the plant cells of resistant line.

\section{Acknowledgment}

The authors appreciate the financial support from National Institute of Genetic Engineering and Biotechnology, NIGEB, to perform the experiments at the University of Udine, Italy during sabbatical position.

\section{References}

1. Kahkonen M, Hopia AI, Heinonen, M. Antioxidant activity of plant extracts containing phenolic compounds. J Agric Food Chem. 1999;47:3954-3962. doi: 10.1021/jf9901461

2. Senkoylu, N, Dale N. Nutritional evaluation of a high-oil sunflower meal in broiler starter diets. J Appl Poult Res. 2006;15:40-47. doi: 10.1093/japr/15.1.40

3. Bolton MD, Thomma BP, Nelson BD. Sclerotinia sclerotiorum (Lib.) de Bary: biology and molecular traits of a cosmopolitan pathogen. Mol Plant Pathol. 2006;7(1):1-16. doi: 10.1111/j.13643703.2005.00316.x.

4. Castaño F, Baldini M, Re J, Vannozzi GP, Rodriguez R, Turi M, Tahmasebi-Enferadi S. Genotypic responses and diallel analysis for an early resistance test to Sclerotinia sclerotiorum in sunflower. OCL. 2002;9(6): 474-478. doi:10.1051/ocl.2002.0474
5. Hegedus DD, Rimmer SR. Sclerotinia sclerotiorum: when "to be or not to be" a pathogen? FEMS Microbiol. Lett. 2005;251(2):17784. doi: 10.1016/j.femsle.2005.07.040.

6. Ershad J. The Fungi of Iran. Agricultural Research and Education Organization Press. 1995. Tehran, Iran. (In Farsi).

7. Kim KS, Min JY, Dickman MB. Oxalic acid is an elicitor of plant programmed cell death during Sclerotinia sclerotiorum disease development. Mol Plant Microbe Interact. 2008;21:605-612. doi: 10.1094/MPMI-21-5-0605.

8. Cessna SG, Sears VE, Dickman MB, Low PS. Oxalic acid, a pathogenicity factor for Sclerotinia sclerotiorum, suppresses the oxidative burst of the host plant. Plant Cell. 2000;12:2191-2199. doi: 10.1105/tpc.12.11.2191.

9. Enferadi ST, Rabiei Z, Vannozzi GP, Akbari GA. Shikimate dehydrogenase expression and activity in sunflower genotypes susceptible and resistant to sclerotinia sclerotiorum (Lib.) de bary. JAST. 2011;13(6): 943-952.

10. Favaron F, Sella L, D'Ovidio R. Relationship among endopolygalacturonase, oxalate, $\mathrm{pH}$, and plant polygalacturonaseinhibiting protein (PGIP) in the interaction between Sclerotinia sclerotiorum and soybean. Mol Plant Microbe Interact. 2004;17:1402-1409. doi: 10.1094/MPMI.2004.17.12.1402.

11. Monazzah, M., Enferadi, S.T., Soleimani, M.J., Rabiei, Z. An unspecific phytotoxin oxalic acid and its effect on sunflower proteome. Aust J Bot. 2017;64(3): 219-226. doi: 10.1071/ BT15143.

12. Heller A, Witt-Geiges T. Oxalic acid has an additional, detoxifying function in Sclerotinia sclerotiorum pathogenesis. PloS One. 2013;8(8):e72292. doi: 10.1371/journal.pone.0072292.

13. Ferrar P, Walker J. o-Diphenol oxidase inhibition — an additional role for oxalic acid in the phytopathogenic arsenal of Sclerotinia sclerotiorum and Sclerotium rolfsii. Physiol. Mol. Plant Pathol. 1993;43(6):415-22. doi: 10.1006/pmpp.1993.1069.

14. Liang Y, Strelkov SE, Kav NNV. Oxalic acid-mediated stress responses in Brassica napus L. Proteomics. 2009;9:3156-3173. doi: 10.1002/pmic.200800966.

15. Xiao X, Xie J, Cheng J, Li G, Yi X, Jiang D, Fu Y. Novel Secretory Protein Ss-Cafl of the Plant-Pathogenic Fungus Sclerotinia sclerotiorum Is Required for Host Penetration and Normal Sclerotial Development. Mol Plant Microbe Interact. 2014 27:1, 40-55. doi: 10.1094/MPMI-05-13-0145-R

16. Less H, Angelovici R, Tzin V, Galili G. Coordinated gene networks regulating Arabidopsis plant metabolism in response to various stresses and nutritional cues. Plant Cell. 2011;23:1264-71. doi: $10.1105 /$ tpc. 110.082867 .

17. Safari Sinegani A, Emtiazi G, Hajrasuliha S. Comparative studies of extracellular fungal laccases under different conditions. JAST: 2010;9:69-76.

18. Attanayake R, Porter L, Johnson D, Chen W. Genetic and phenotypic diversity and random association of DNA markers of isolates of the fungal plant pathogen Sclerotinia sclerotiorum from soil on a fine geographic scale. Soil Biol. Biochem. 2012;55:28-36. doi: 10.1016/j.soilbio.2012.06.002.

19. Tahmasebi Enferadi S, Vannozzi G, Gomez-Sanchez D, Baldini M. Results of screening sunflower for resistance to toxic metabolites produced by Sclerotinia sclerotiorum (Lib.) de Bary and prospects for the use of biochemical markers in breeding. Agric Mediterr. 1998;128(1):47-58.

20. Livak KJ, Schmittgen TD. Analysis of relative gene expression data using real-time quantitative PCR and the $2^{-\triangle \Delta C T}$ method. Methods. 2001;25(4):402-8. doi: 10.1006/meth.2001.1262. 
21. Liang, Y, Srivastava, S, Rahman, MH, Strelkov, SE, Kav, NNV. Proteome changes in leaves of Brassica napus L. as a result of Sclerotinia sclerotiorum challenge. J Agric Food Chem. 2008;56:963-1976. doi: 10.1021/jf073012d.

22. Bradford MM. A rapid and sensitive method for the quantitation of microgram quantities of protein utilizing the principle of protein-dye binding. Anal Biochem. 1976;72(1-2):248-54. doi: 10.1016/0003-2697(76)90527-3.

23. O'Farrell PH. High resolution two-dimensional electrophoresis of proteins. JBC. 1975;250(10):4007-21.

24. Escobar-Tovar L, Guzmán-Quesada M, Sandoval-Fernández JA, Gómez-Lim MA. Comparative analysis of the in vitro and in planta secretomes from Mycosphaerella fijiensis isolates. Fungal Biol. 2015;119(6):447-70. doi: 10.1016/j.funbio.2015.01.002.

25. Heath RL, Packer L. Photoperoxidation in isolated chloroplasts: I. Kinetics and stoichiometry of fatty acid peroxidation. Arch Biochem Biophys. 1968;125(1):189-98. doi: 10.1016/00039861(68)90654-1.

26. Fristensky B, Balcerzak M, He D, Zhang P. Expressed sequence tags from the defense response of Brassica napus to Leptosphaeria maculans. Mol Plant Pathol. 1999;50: 23-28.

27. Subramanian B, Bansal VK, Kav NN. Proteome-level investigation of Brassica carinata-derived resistance to Leptosphaeria maculans. J Agric Food Chem.2005;53:313-324. doi: 10.1021/ jf048922z

28. Liang X, Zhang L, Natarajan SK, Becker DF. Proline mechanisms of stress survival. Antioxid Redox Signal. 2013;19(9):998-1011. doi: 10.1089/ars.2012.5074.

29. Chen C, Dickman MB. Proline suppresses apoptosis in the fungal pathogen Colletotrichum trifolli. Proc Natl Acad Sci. 2005;102:3459-3464. doi: 10.1073/pnas.0407960102

30. Moghaddam MR, Van den Fude W. Sugars and plant innate immunity. J of Exp Bot. 2012;63(11):3989-98 doi:10.1093/jxb.

31. Solfanelli C, Poggi A, Loreti E, Alpi A, Perata P. Sucrose specific induction of the anthocyanin biosynthetic pathway in Arabidopsis. Plant Physiol.2006;140:637-646. doi: 10.1104/pp.105.072579.

32. Lehninger AL. Biochimica secondo edizione. Biosintesi degli amino acidi aromatici fenilalanina e triptofano. Freeman, W. H. \& Company. 1979; 639-641.

33. Diaz J, Bernal A, Pomar F, Merino F. Induction of shikimate dehydrogenase and peroxidase in pepper (Capsicum annuum L.) seedlings in response to copper stress and its relation to lignification. Plant Sci. 2001;161:179-188. doi: 10.1016/S01689452(01)00410-1

34. Miklas PN, Grafton K, McClean P. Estimating phenylalanine ammonia lyase activity in common beans inoculated with Sclerotinia sclerotiorum. Hort Sci.1993;28:937-938.

35. Cook, NC, Samman, S. Flavonoids chemistry, metabolism, cardioprotective effects, and dietary sources. J Nutr Biochem. 1996;7:66 76. doi: 10.1016/0955-2863(95)00168-9.

36. Winkel-Shirley B. Flavonoid biosynthesis: A colorful model for genetics, biochemistry, cell biology, and biotechnology. Plant Physiol.2001;126:485-93. doi: 10.1104/pp.126.2.485.

37. Menden B, Kohlhoff M, Moerschbacher B. Wheat cells accumulate a syringyl-rich lignin during the hypersensitive resistance response. Phytochemistry. 2007;68:513-520. doi: 10.1016/j.phytochem.2006.11.011.

38. Rojas CM, Senthil-Kumar M, Tzin V, Mysore KS. Regulation of primary plant metabolism during plant-pathogen interactions and its contribution to plant defense. Front Plant Sci. 2014;5. doi: 10.3389/fpls.2014.00017.
39. Zhu L, Liu X, Liu X, Jeannotte R, Reese JC, Harris M, et al. Hessian fly (Mayetiola destructor) attack causes a dramatic shift in carbon and nitrogen metabolism in wheat. Mol Plant-Microbe Interact. 2008;21(1):70-8. doi: 10.1094/MPMI-21-1-0070.

40. Parker D, Beckmann M, Zubair H, Enot DP, Caracuel-Rios Z, Overy DP, et al. Metabolomic analysis reveals a common pattern of metabolic re-programming during invasion of three host plant species by Magnaporthe grisea. Plant J. 2009;59(5):723-37. doi: 10.1111/j.1365-313X.2009.03912.x.

41. Voll, et al., Metabolic analysis of fungus-infected cereals. Front Plant Sci. 2011;2:39- 51. doi:10.3389/fpls.2011.00039.

42. Kim JY, Wu J, Kwon SJ, Oh H, Lee SE, Kim SG, et al. Proteomics of rice and Cochliobolus miyabeanus fungal interaction: insight into proteins at intracellular and extracellular spaces. Proteomics. 2014;14(20):2307-18. doi: 10.1002/pmic.201400066.

43. Prats E, Bazzalo M, Leon A, Jorrin J. Accumulation of soluble phenolic compounds in sunflower capitula correlates with resistance to Sclerotinia sclerotiorum. Euphytica. 2003;132(3):321-9. doi: 10.1023/A:1025046723320.

44. Rodriguez M, Venedikian N, Bazzalo M, Godeas A. Histopathology of Sclerotinia sclerotiorum attack on flower parts of Helianthus annuus heads in tolerant and susceptible varieties. Mycopathologia. 2004;157(3):291-302. doi: 10.1023/B:MYCO.0000024177.82916.b7.

45. Monazzah, M., Soleimani, MJ, Tahmasebi Enferadi, S and Rabiei, Z. Effects of oxalic acid and culture filtrate of Sclerotinia sclerotiorum on metabolic changes in sunflower evaluated using FT-IR spectroscopy. J Gen Plant Pathol. 2018;84(1): 2-11. doi: 10.1007/s10327-017-0755-2.

46. Cardoso DC, Martinati JC, Giachetto PF, Vidal RO, Carazzolle MF, Padilha L, et al. Large-scale analysis of differential gene expression in coffee genotypes resistant and susceptible to leaf miner-toward the identification of candidate genes for marker assisted-selection. BMC Genomics. 2014;15(1):66. doi: 10.1186/1471-2164-15-66.

47. Graham IA, Leaver CJ, Smith SM. Induction of malate synthase gene expression in senescent and detached organs of cucumber. Plant Cell. 1992;4(3):349-57. doi: 10.1105/tpc.4.3.349.

48. Lorenz L, Michael L, Gerald F. Life and death in a macrophage: role of the glyoxylate cycle in virulence. Eukaryot Cell. 2002;1:657-662. doi: 10.1128/EC.1.5.657-662.2002.

49. Cherry, JH, Locy, R, Rychter, A. Plant Tolerance to Abiotic Stresses in Agriculture. Role of Genetic Engineering. 2000. Springer.

50. Scheideler M, Schlaich NL, Fellenberg K, Beissbarth T, Hauser $\mathrm{NC}$, Vingron $\mathrm{M}$, et al. Monitoring the switch from housekeeping to pathogen defense metabolism in Arabidopsis thaliana using cDNA arrays. J Biol Chem. 2002;277(12):10555-61. doi: 10.1074/ jbc.M104863200.

51. De Bellis L, Nishimura M. Development of enzymes of the glyoxylate cycle during senescence of pumpkin cotyledons. Plant Cell Physiol. 1991;32(4):555-61.

52. Pistelli L, De Bellis L, Alpi A. Peroxisomal enzyme activities in attached senescing leaves. Planta. 1991;184(1):151-3. doi: 10.1007/BF00208249.

53. Naton B, Hahlbrock K, Schmelzer E. Correlation of rapid cell death with metabolic changes in fungus-infected, cultured parsley cells. Plant Physiol. 1996;112(1):433-44. doi: 10.1104/ pp.112.1.433.

54. Yasar F, Ellialtioglu S, Yildiz K. Effect of salt stress on antioxidant defense systems, lipid peroxidation, and chlorophyll content in green bean. Russ J Plant Physiol. 2008;55(6):782-6. doi: 10.1134/ 
S1021443708060071.

55. Demiral T, Türkan I. Comparative lipid peroxidation, antioxidant defense systems and proline content in roots of two rice cultivars differing in salt tolerance. Environ. Exp. Bot. 2005;53(3):247-57. doi: 10.1016/j.envexpbot.2004.03.017.

56. Lyon G.D., Goodman B.A. \& Williamson B. 2004. Botrytis cinerea perturbs redox processes as an attack strategy in plants, pp 119-141. In: Elad Y., Williamson B., Tudzynski P. \& Delen
N. (eds), Botrytis: Biology, Pathology and Control. Kluwer Academic Publishers, Dordrecht, The Netherlands.

57. Peluffo L, Lia V, Troglia C, Maringolo C, Norma P, Escande A, et al. Metabolic profiles of sunflower genotypes with contrasting response to Sclerotinia sclerotiorum infection. Phytochemistry. 2010;71(1):70-80. doi: 10.1016/j.phytochem.2009.09.018

58. Mengiste T. Plant immunity to necrotrophs. Annu Rev Phytopathol. 2012;50:267-294. doi: 10.1146/annurev-phyto-081211-172955. 